\title{
Demersal Fish Fauna of the Continental Slope off Nova Scotia, Canada, Based on Exploratory Bottom Trawl Surveys in 1994-95
}

\author{
R. G. Halliday ${ }^{1,3}$, L. Van Guelpen ${ }^{2}$ and D. E. Themelis ${ }^{1}$ \\ ${ }^{1}$ Science Branch, Department of Fisheries and Oceans Canada, Bedford Institute of Oceanography, \\ Dartmouth, N.S., Canada, B2Y 4A2 \\ ${ }^{2}$ Atlantic Reference Centre, Huntsman Marine Science Centre, 1 Lower Campus Road, \\ St. Andrews, N.B., Canada, E5B 2L7
}

Halliday R. G., L. Van Guelpen and D. E. Themelis. 2012. Demersal fish fauna of the continental slope off Nova Scotia, Canada, based on exploratory bottom trawl surveys in 1994-95. J. Northw. Atl. Fish. Sci., 44: 41-60. doi:10.2960/J.v44.m681

\begin{abstract}
The demersal fish fauna at 900-1800 m depths off Nova Scotia, Canada, is described using data from exploratory bottom trawl surveys conducted in November 1994 and March 1995 by a commercial fishing trawler. Approximately 25 metric tons (39 000 specimens) of demersal fish belonging to at least 82 species were caught, $30 \%$ of which had not previously been recorded from the area. However, more than half the catch consisted of the two species Centroscyllium fabricii (black dogfish) and Coryphaenoides rupestris (roundnose grenadier). Catches were higher in the shallower depth strata fished and cluster analysis showed that depth was the primary factor determining species composition of catches. It is suspected, however, that the vessel fished less effectively at depths greater than about $1500 \mathrm{~m}$, contributing to the reduction in catch quantities at these depths. The importance in catches of large bodied species, particularly Chimaeriformes and sharks, contrasts with results from surveys in adjacent areas. This likely reflects the greater fishing power of the vessel/gear used in present surveys rather than real differences in faunal composition. Catches of mesopelagic species during these surveys, and during an earlier deepwater trawling survey in this area, are also described.
\end{abstract}

Keywords: Centroscyllium fabricii; Coryphaenoides rupestris; distribution; deepsea fish; Scotian Shelf slope

(C) Her Majesty the Queen in right of Canada, 2012

\section{Introduction}

In the early 1990s, interest by the Canadian fishing industry in developing fisheries for new species in deep water provided an opportunity for a joint Industry Government venture to explore the commercial potential of fish resources on the Scotian Shelf slope, south of Nova Scotia. The only previous survey of the demersal fish fauna in this area had been conducted by a research vessel, and sampling was restricted to depths shallower than $1200 \mathrm{~m}$ (Markle et al., 1988). The presently reported surveys were conducted by a commercial fishing trawler in November 1994 and in March 1995, at bottom depths of $910-1830 \mathrm{~m}$. This paper reports on the fish catches made during these surveys, examines patterns in species distributions, and compares results with those of Markle et al. (1988), and with those from other studies in adjacent geographical areas.

An account of catches of pelagic fish species made during these 1994-95 surveys is provided also. Markle et al. (1988) did not include pelagic fish catches in their report, but their records were available to the authors of the present study and are provided here for comparison with 1994-95 catches. 


\section{Methods}

The surveys were conducted by the commercial fishing trawler Cape Chidley (length - $43 \mathrm{~m}$; tonnage - 792; horsepower - 2400) on 6-16 November 1994 and 7-16 March 1995 (labelled C19 and C20 respectively). A commercial Engel high-lift bottom trawl was used with $1500 \mathrm{~kg}$ polyvalent trawl doors and a $51.8 \mathrm{~m}$ footrope equipped with 53 and $61 \mathrm{~cm}$ disc rock-hopper foot gear. Netting was of regulation $145 \mathrm{~mm}$ mesh but a $30 \mathrm{~mm}$ small mesh liner was inserted in the belly extension and codend to retain small specimens and a $20 \mathrm{~mm}$ diameter tickler chain was attached ahead of the footrope to enhance capture of bottom dwelling fauna. A headline transducer was deployed on all tows to measure vertical opening of the net. Headline height was typically about $6 \mathrm{~m}$ and no marked differences were observed between surveys or among depth zones. No instrumentation was available to measure horizontal net opening but, according to the vessel owners, previous performance data for this net (in shallower waters) indicated that the normal spread from wingtip to wingtip was $24 \mathrm{~m}$ and between the trawl doors was $69 \mathrm{~m}$.

Sampling was stratified by area and depth, and fishing locations within strata were chosen randomly. On the first survey (C19), four discrete areas were fished. These were located south of Browns, LaHave, Western and Banquereau banks (Fig. 1, top panel). During the second survey (C20), four larger, contiguous, areas located south of Browns, LaHave, Emerald and Western - Sable Island banks were fished (Fig.1, bottom panel). Each fishing area was divided into five depth strata at $100 \mathrm{fm}(183 \mathrm{~m})$ intervals, but for presentation of data, stratum boundaries are defined in metres (rounded to the nearest $10 \mathrm{~m}$ ). Fishing was conducted on a 24-hour basis, and stations were occupied in the order that minimized transit time.

The vessel's standard fishing procedure was to tow the net at 3.0 knots for one hour, measured from completion of shooting to start of haul back. However, there was insufficient trawl warp to maintain the same scope for deeper as for shallower tows and towing speed had to be reduced to 2.5 knots for the two deepest strata to get the net on bottom. Also, the actual start of trawling was taken as the time that resistance was felt due to bottom contact and it was found that actual time on bottom varied from 51 minutes in the shallowest, to 46 minutes in the deepest, stratum. Thus, distance towed was about 2.5 nautical miles for tows in the three shallowest strata, but the lower towing speed and reduced time on bottom for tows in the deeper strata resulted in the distance towed in the 1460-1650 m stratum being about 0.80 , and in the $1650-1830 \mathrm{~m}$ stratum being about 0.75 , of that in the shallower strata. Thus, abundance estimates for these deep strata were adjusted by $x 1.25$ and $x 1.33$ respectively.
The at-sea scientific protocol was to obtain the weight, number and length frequency (total length to the nearest $\mathrm{cm}$ ) of each taxon in every catch. Particularly large catches of a taxon were sub-sampled by weight, numbers and length compositions subsequently being adjusted by the ratio of total to sample weight. Species that occurred in high volume were either retained by the vessel for commercial purposes or discarded, with scientific personnel retaining voucher specimens. In addition, a miscellany of taxa that occurred rarely, or that were recognized as presenting identification difficulties, was retained. All kept specimens were identified subsequently by the authors and the at-sea records were edited based on these laboratory results. In the majority of cases, voucher specimens confirmed at-sea species identifications but, in some, the taxonomic situation proved more complex than initially recognized at sea. In the latter circumstance, the authors reassigned taxonomic designations at the species level when the evidence was convincing but to higher taxonomic levels in the other cases. All retained specimens were deposited at the Atlantic Reference Centre (ARC), Huntsman Marine Science Centre (HMSC), St. Andrews, New Brunswick, Canada. Taxonomy follows Eschmeyer and Fricke (2012).

Comparisons of catches between areas, depths and surveys were restricted to those tows that were considered 'problem free'. Problematic tows were defined as those during which severe damage to the net occurred, when tow time was substantially reduced due to hang-ups on bottom obstacles, or when catches contained atypically low numbers of demersal species, indicating that the net was fishing off bottom. Species compositions were compared among stations using Bray-Curtis similarity coefficients following fourth root transformation of abundance data. Samples were partitioned using the CLUSTER routine in PRIMER version six (Clarke and Gorley, 2006). Length frequencies (by $3 \mathrm{~cm}$ groups) and mean lengths were calculated for the five species that contributed most to catches (by weight) by combining numbers per tow at length within each depth zone for two areas, Northwest Atlantic Fisheries Organization (NAFO) Divisions 4X (Browns -LaHave sampling areas) and 4W (Emerald-Western-Sable banks sampling areas). Estimates of the area of bottom within each depth/NAFO Division category (DFO: unpublished) were then used to obtain the following depth strata/Division weightings for amalgamation of the data from each survey:

\begin{tabular}{rcc}
\hline Stratum $(\mathrm{m})$ & $4 \mathrm{X}$ & $4 \mathrm{~W}$ \\
\hline $910-1100$ & 0.05 & 0.09 \\
$1100-1280$ & 0.06 & 0.10 \\
$1280-1460$ & 0.08 & 0.12 \\
$1460-1650$ & 0.09 & 0.14 \\
$1650-1830$ & 0.12 & 0.15 \\
\hline & 0.40 & 0.60 \\
\hline
\end{tabular}


HALLIDAY et al:: Demersal Fish Fauna off Nova Scotia, Canada, from Surveys in 1994-95.
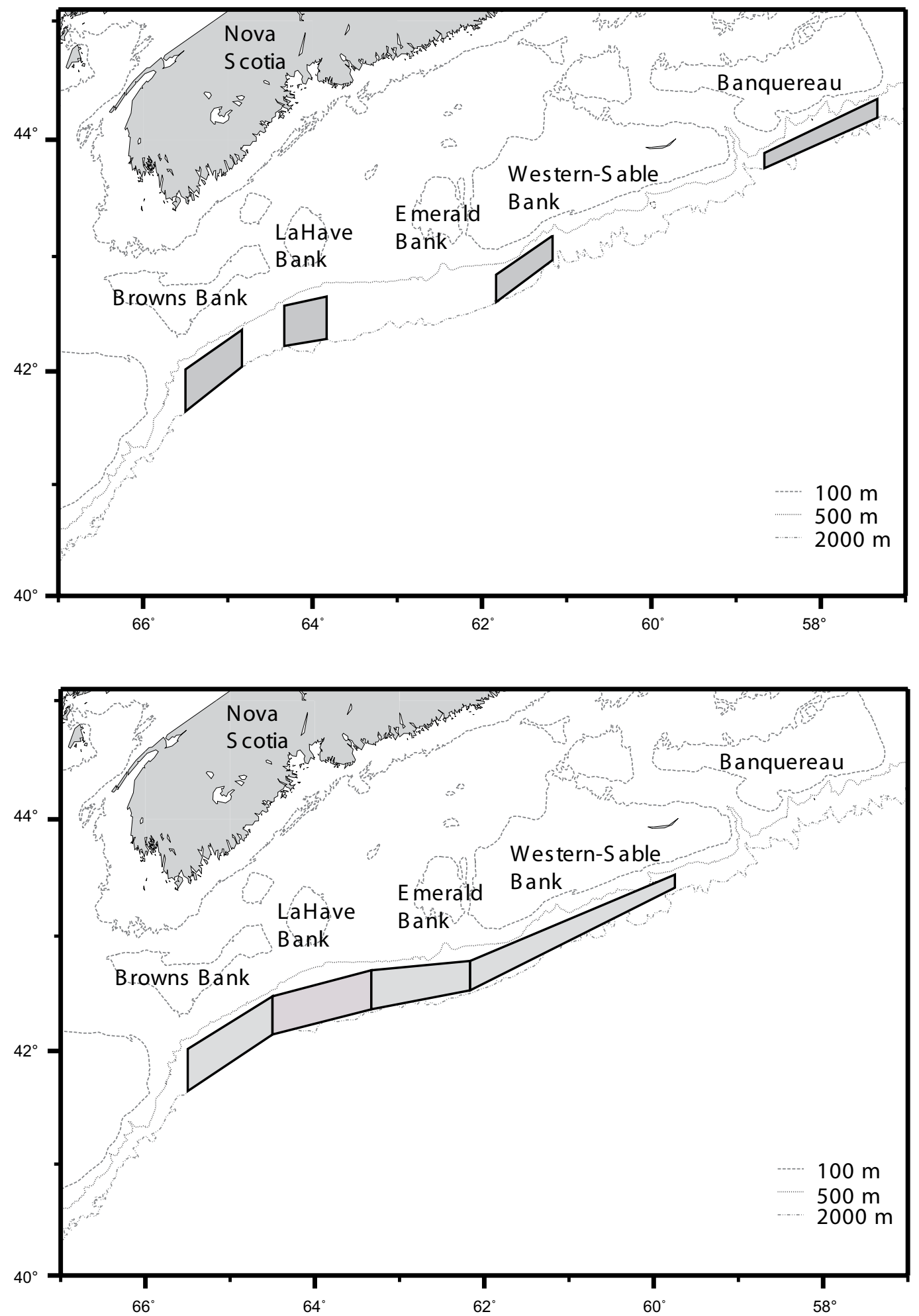

Fig. 1. Areas fished by the Cape Chidley: top panel - C19, November 1994, bottom panel - C20, March 1995. 
Distributional records in the primary literature were used to determine which species in the present collections had not previously been reported from the study area. Online sources based on shared, disparate data collections were utilized only when records of interest could be verified through personal communication. The assignment of taxa to demersal or pelagic categories was based on their designations by Moore et al. (2003), species listed by them as benthic or benthopelagic in habit being classed here as demersal, and others as pelagic species. Common names, in Tables 1 and 2, follow usage by presently cited authors, particularly Moore et al. (2003), but cannot be provided for all species as some do not have accepted common names. Depth categorizations, upper slope (200-750 m), mid slope (750-1500 m) and lower slope (1500-2250 m), follow Haedrich and Merrett (1988). The Northwest Atlantic is equated to the NAFO Statistical Area.

\section{Results}

The surveys were largely successful in implementing a stratified-random sampling design with at least two sampling locations being fished in each depth stratum in each fishing area. Fishing areas differed between surveys, however (Fig. 1). On C19, the rate of successful completion of tows in the Banquereau area was low, only six of the 11 tows made there being classifiable as problem free, and thus this area was excluded from the sampling plan for C20. The sampling areas on C20 were contiguous and encompassed the other, discrete, areas used on C19. In these areas, 29 (of 31) tows on C19, and 44 (of 47) tows on C20, were considered problem free. It is the data from these tows that were used in analyses of geographic and bathymetric distributions, and size compositions. However, catches made in the Banquereau area on C19 are described separately and included in the listing of catches overall.

\section{Demersal Species}

\section{Taxonomic composition}

Approximately 25 metric tons (39 000 specimens) of demersal fish, belonging to at least 82 species, were caught (Tables 1 and 2). Among these, 10 taxa accounted for $90 \%$ of the catch by weight and these 10 accounted also for $80 \%$ by number. More than half the catch (by weight and number) consisted of Centroscyllium fabricii and Coryphaenoides rupestris.

For instances in Table 1 where catches are reported at a taxonomic level higher than species, the predominant species can be inferred quite reliably when voucher specimens were available (Table 2), e.g. it is likely that most of the fish listed as Rajidae NS in Table 1 were Amblyraja jenseni. Inferences about the abundance of the secondary species in a category relative to the primary species would be inappropriate, however. This is because relatively few voucher specimens were kept for abundant species, but most or all specimens of taxa recognized as 'different' were retained. Records reported in Table 1 at the family level that were not supported by voucher specimens (Alepocephalidae, Ipnopidae, Ophidiformes, Gadiformes and Zoarcidae) are mostly of little numerical importance and consist of inadequately documented records. There are, in addition, two special cases:

- Apristurus spp.: Markle et al. (1988) recognized two forms in their catches but (Moore et al., 2003) listed four species as possibly occurring off New England, all of which might occur also in the present study area. See also Hartel et al. (2008).

- Bathyraja spp.: while species-level identifications were recorded at sea, there was an association between identifications and surveys (two B. richardsoni on C19, two B. spinicauda on C20) that raises doubt about their reliability. Thus, the species level identifications were not accepted.

Almost 30\% (23) of the species listed in Tables 1 and 2 had not been recorded previously from off Nova Scotia. Thirteen of these new records were of species documented as having ranges that include adjacent areas, primarily to the southwest off New England (Moore et al., 2003), and thus they represent only minor range extensions. The remaining 10 species are ones that previously have not been recorded, or have been recorded only rarely, from the NAFO Statistical Area, i.e. north of Cape Hatteras $\left(35^{\circ} \mathrm{N}\right)$. Capture information, ARC catalogue numbers, and distributional notes are provided for these in Table 3.

Among the minor range extensions, it is noteworthy that the records of Rajella bathyphila are not in conformance with the convention accepted by Moore et al. (2003) that this species does not occur southwest of the Grand Banks (and thus that all records to the southwest must be of the closely-related Rajella bigelowi). More recently, Sulak et al. (2009) ignored this convention by recording $R$. bathyphila from the Mid-Atlantic-Bight. The latter authors are followed here, as the two specimens from off Western Bank had total lengths of 92 and $96 \mathrm{~cm}$, greatly exceeding the maximum length of $50 \mathrm{~cm}$ that has been recorded for R. bigelowi (Sulak et al., 2009).

\section{Geographic and bathymetric distributions}

Variation with depth of the catch rate (no. and wt. per tow) of all demersal species combined showed a similar pattern in both surveys (Fig. 2), with highest values occurring in one of the two shallowest strata and lowest values in one of the two deepest strata. The average time 
Table 1. Demersal taxa: total number (No.) and weight (Wt.) caught and depth range of captures $\left(\mathrm{D}_{\min }\right.$ and $\mathrm{D}_{\max }-\mathrm{minimum}$ and maximum depths fished during tows in which the taxon was caught). (* - range extension, ${ }^{* *}$ - not or seldom recorded previously from the NW Atlantic (see Table 3), (1) - see Table 2 for supplementary information on species composition, (2) - published by Caruso (2002).)

\begin{tabular}{|c|c|c|c|c|c|c|}
\hline Order/Family & Species (or lowest taxon) & Common Name & No. & Wt. (kg) & $\mathrm{D}_{\min }(\mathrm{m})$ & $\mathrm{D}_{\max }(\mathrm{m})$ \\
\hline \multicolumn{7}{|l|}{ Chimaeriformes } \\
\hline Chimaeridae & Hydrolagus affinis & Deepwater chimaera & 107 & 354 & 971 & 1820 \\
\hline \multirow[t]{2}{*}{ Rhinochimaeridae } & Harriotta raleighana & Longnose chimaera & 904 & 1118 & 909 & 1820 \\
\hline & Rhinochimaera atlantica & Knifenose chimaera & 129 & 354 & 909 & 1750 \\
\hline \multicolumn{7}{|l|}{ Carcharhiniformes } \\
\hline Scyliorhinidae & Apristurus spp. & Catsharks & 707 & 1037 & 913 & 1820 \\
\hline \multicolumn{7}{|l|}{ Squaliformes } \\
\hline Somniosidae & Centroscymnus coelolepis & Portuguese shark & 262 & 688 & 940 & 1778 \\
\hline \multirow[t]{2}{*}{ Etmopteridae } & Centroscyllium fabricii & Black dogfish & 10572 & 7816 & 909 & 1809 \\
\hline & Etmopterus princeps & Rough sagre & 545 & 548 & 918 & 1776 \\
\hline Squalidae & Squalus acanthias & Spiny dogfish & 1 & 3 & 1280 & 1428 \\
\hline \multicolumn{7}{|l|}{ Rajiformes } \\
\hline Arhynchobatidae & Bathyraja spp. & - & 4 & 62 & 940 & 1820 \\
\hline \multirow[t]{3}{*}{ Rajidae } & Rajella bathyphila* & Deepwater ray & 2 & 16 & 1094 & 1256 \\
\hline & Rajella bigelowi & Bigelow's ray & 37 & 12 & 940 & 1820 \\
\hline & Rajidae NS (1) & & 75 & 74 & 909 & 1803 \\
\hline \multicolumn{7}{|l|}{ Notacanthiformes } \\
\hline \multirow[t]{3}{*}{ Halosauridae } & Aldrovandia spp. (1) & - & 424 & 18 & 909 & 1803 \\
\hline & Halosaurus guentheri* & - & 1 & 1 & 940 & 1074 \\
\hline & Halosauropsis macrochir & - & 311 & 110 & 918 & 1820 \\
\hline \multirow[t]{3}{*}{ Notacanthidae } & Lipogenys gillii & Backfin tapirfish & 3 & 1 & 1333 & 1748 \\
\hline & Notacanthus chemnitzii & Snubnosed spiny eel & 48 & 32 & 909 & 1809 \\
\hline & Polyacanthonotus rissoanus & Shortspine tapirfish & 10 & 1 & 940 & 1717 \\
\hline \multicolumn{7}{|l|}{ Anguillformes } \\
\hline \multirow[t]{3}{*}{ Synaphobranchidae } & Ilyophis brunneus & - & 15 & 1 & 958 & 1695 \\
\hline & Simenchelys parasitica & Snubnose eel & 350 & 61 & 909 & 1820 \\
\hline & Synaphobranchus kaupii & Northern cutthroat eel & 3189 & 497 & 909 & 1820 \\
\hline Nettastomatidae & Venefica procera & - & 20 & 4 & 1280 & 1820 \\
\hline \multicolumn{7}{|l|}{ Osmeriformes } \\
\hline \multirow[t]{8}{*}{ Alepocephalidae } & Alepocephalus agassizii & Agassiz' smoothhead & 4330 & 1908 & 913 & 1820 \\
\hline & Alepocephalus australis & - & 2 & 1 & 1240 & 1655 \\
\hline & Alepocephalus bairdii & Baird's smoothhead & 93 & 241 & 953 & 1794 \\
\hline & Bajacalifornia megalops & Bigeye smoothhead & 20 & 6 & 940 & 1803 \\
\hline & Bathytroctes microlepis* & Smallscale smoothhead & 1 & 0 & 1747 & 1794 \\
\hline & Narcetes stomias & Blackhead salmon & 28 & 35 & 1531 & 1820 \\
\hline & Rouleina attrita & Softskin smoothhead & 564 & 259 & 953 & 1820 \\
\hline & Alepocephalidae NS & - & 82 & 36 & 909 & 1611 \\
\hline \multicolumn{7}{|l|}{ Aulopiformes } \\
\hline Bathysauridae & Bathysaurus ferox & - & 90 & 38 & 913 & 1820 \\
\hline \multirow[t]{7}{*}{ Ipnopidae } & Bathypterois dubius $* *$ & Spiderfish & 5 & 1 & 1483 & 1629 \\
\hline & Bathypterois grallator* & Tripodfish & 1 & 0 & 1710 & 1803 \\
\hline & Bathypterois phenax* & Blackfin spiderfish & 3 & 0 & 940 & 1776 \\
\hline & Bathypterois quadrifilis & - & 19 & 0 & 940 & 1664 \\
\hline & Bathypterois viridensis* & - & 3 & 0 & 1313 & 1565 \\
\hline & Bathytyphlops marionae* & - & 2 & 1 & 1377 & 1459 \\
\hline & Ipnopidae NS & - & 6 & 0 & 940 & 1556 \\
\hline Notosudidae & Scopelosaurus lepidus & - & 4 & 1 & 940 & 1547 \\
\hline \multicolumn{7}{|l|}{ Ophidiiformes } \\
\hline Ophidiidae & Barathrites parri** & - & 2 & 0 & 1384 & 1533 \\
\hline
\end{tabular}


Table 1. (Continued).

\begin{tabular}{|c|c|c|c|c|c|c|}
\hline Order/Family & Species (or lowest taxon) & Common Name & No. & Wt. (kg) & $\mathrm{D}_{\min }(\mathrm{m})$ & $\mathrm{D}_{\max }(\mathrm{m})$ \\
\hline & Barathrodemus manatinus* & - & 1 & 0 & 1313 & 1428 \\
\hline & Bassogigas gillii & - & 12 & 16 & 913 & 1820 \\
\hline & Dicrolene introniger & - & 295 & 37 & 913 & 1776 \\
\hline & Monomitopus agassizii* & - & 2 & 0 & 971 & 1015 \\
\hline \multirow[t]{2}{*}{ Bythitidae } & Cataetyx laticeps $* *$ & - & 1 & 1 & 1384 & 1423 \\
\hline & Ophidiformes NS & - & 4 & 0 & 634 & 901 \\
\hline \multicolumn{7}{|l|}{ Gadiformes } \\
\hline \multirow[t]{8}{*}{ Macrouridae } & Cetonurus globiceps $* *$ & - & 1 & 0 & 1672 & 1748 \\
\hline & Coelorinchus occa?* & Swordsnout grenadier & 1 & 1 & 1500 & 1618 \\
\hline & Coryphaenoides rupestris & Roundnose grenadier & 9605 & 7046 & 909 & 1820 \\
\hline & Coryphaenoides spp. (1) & Grenadiers & 738 & 28 & 918 & 1803 \\
\hline & Gadomus arcuatus** & - & 2 & 1 & 913 & 1068 \\
\hline & Macrourus berglax & Roughhead grenadier & 140 & 228 & 909 & 1794 \\
\hline & Nezumia bairdii & Marlinspike & 3203 & 270 & 909 & 1809 \\
\hline & Macrouridae NS (1) & - & 77 & 17 & 1130 & 1820 \\
\hline \multirow[t]{4}{*}{ Moridae } & Antimora rostrata & Blue hake & 633 & 383 & 909 & 1820 \\
\hline & Guttigadus latifrons $* *$ & - & 1 & 0 & 1682 & 1820 \\
\hline & Halargyreus johnsonii & Dainty mora & 22 & 10 & 1130 & 1820 \\
\hline & Laemonema barbatulum & Smallscale mora & 4 & 0 & 940 & 1522 \\
\hline \multirow[t]{2}{*}{ Lotidae } & Gaidropsarus argentatus & Silver rockling & 1 & 0 & 1362 & 1469 \\
\hline & Gaidropsarus ensis & Threebeard rockling & 258 & 119 & 1033 & 1820 \\
\hline \multirow[t]{3}{*}{ Phycidae } & Phycis chesteri & Longfin hake & 115 & 29 & 909 & 1778 \\
\hline & Urophycis tenuis & White hake & 11 & 23 & 913 & 1613 \\
\hline & Gadiformes NS & - & 32 & 0 & 1077 & 1533 \\
\hline \multicolumn{7}{|l|}{ Lophiformes } \\
\hline Chaunacidae & Chaunacops roseus $*(2)$ & - & 1 & 0 & 1653 & 1743 \\
\hline Ogcocephalidae & Dibranchus atlanticus & Atlantic batfish & 1 & 0 & 1324 & 1346 \\
\hline \multicolumn{7}{|l|}{ Zeiformes } \\
\hline Oreosomatidae & Neocyttus helgae* & - & 15 & 9 & 971 & 1820 \\
\hline \multicolumn{7}{|l|}{ Scorpaeniformes } \\
\hline Psychrolutidae & Cottunculus thomsonii & Pallid sculpin & 194 & 208 & 909 & 1646 \\
\hline Liparidae & Paraliparis spp. (1) & Snailfishes & 50 & 1 & 909 & 1717 \\
\hline \multicolumn{7}{|l|}{ Perciformes } \\
\hline \multirow[t]{2}{*}{ Anarhichadidae } & Anarhichas denticulatus & Northern wolffish & 1 & 23 & 1357 & 1428 \\
\hline & Anarhichas minor & Spotted wolffish & 2 & 2 & 953 & 1646 \\
\hline \multirow[t]{4}{*}{ Zoarcidae } & Lycodonus mirabilis & - & 9 & 0 & 1287 & 1695 \\
\hline & Lycodes terraenovae & Atlantic eelpout & 39 & 6 & 918 & 1772 \\
\hline & Pachycara crassiceps $* *$ & - & 2 & 1 & 1646 & 1693 \\
\hline & Zoarcidae NS & - & 1 & 0 & 1280 & 1428 \\
\hline \multicolumn{7}{|l|}{ Pleuronectiformes } \\
\hline \multirow[t]{3}{*}{ Pleuronectidae } & Glyptocephalus cynoglossus & Witch flounder & 30 & 6 & 909 & 1629 \\
\hline & Hippoglossus hippoglossus & Atlantic halibut & 4 & 50 & 918 & 1256 \\
\hline & Reinhardtius hippoglossoides & Greenland halibut & 575 & 1601 & 909 & 1820 \\
\hline
\end{tabular}

of day that fishing occurred did not vary systematically with depth. Thus, time of sampling in relation to diurnal vertical migration patterns does not explain the observed progressive decline in catch rates in the three deepest strata in both surveys. The number of demersal taxa caught per tow did not vary with depth but was about 19 on C19 and 22 on C20. There was a broad similarity in catch rates among areas and between surveys except that, on $\mathrm{C} 20$, catch rates in 1100-1280 $\mathrm{m}$ and 1280-1460 m strata in the LaHave area were more than double those in other areas. These high catches were composed primarily of $C$. rupestris. 
Table 2. Supplementary information on the demersal species contributing to cases where taxa are grouped at genus or family level in Table 1, from laboratory identifications of retained specimens. (No. - number of specimens identified. * - range extension, ${ }^{* *}$ - not or seldom recorded previously from the NW Atlantic (see Table 3).)

\begin{tabular}{|c|c|c|c|}
\hline Taxon & Species & Common Name & No. \\
\hline \multirow[t]{2}{*}{ Rajidae NS } & Amblyraja jenseni & shorttail skate & 8 \\
\hline & Rajella fyllae & round skate & 1 \\
\hline \multirow[t]{4}{*}{ Aldrovandia spp. } & Aldrovandia affinis & - & 10 \\
\hline & Aldrovandia gracilis** & - & 10 \\
\hline & Aldrovandia oleosa & - & 4 \\
\hline & Aldrovandia phalacra & - & 83 \\
\hline \multicolumn{4}{|c|}{ Coryphaenoides spp. ${ }^{1}$ and } \\
\hline \multirow[t]{6}{*}{ Macrouridae $\mathrm{NS}^{2}$} & Coryphaenoides alateralis $* *$ & - & 1 \\
\hline & Coryphaenoides armatus & abyssal grenadier & 1 \\
\hline & Coryphaenoides carapinus & - & 44 \\
\hline & Coryphaenoides guentheri & Günther's grenadier & 5 \\
\hline & Coryphaenoides mediterraneus $* *$ & - & 4 \\
\hline & Nezumia longebarbata* & - & 1 \\
\hline \multirow[t]{2}{*}{ Liparidae } & Paraliparis copei & Blacksnout snailfish & 19 \\
\hline & Paraliparis garmani & Pouty snailfish & 3 \\
\hline
\end{tabular}

${ }^{1}$ Predominantly C. carapinus

${ }^{2}$ Predominantly $C$. guentheri

Cluster analyses based on catch numbers (Fig. 3) resulted in dendrograms showing that the depth strata were more important in ordering the stations than sampling area. For $\mathrm{C} 19$, three station groups formed, one containing the two tows in the shallowest stratum off Browns Bank, a second composed of the remaining tows in the three shallowest strata plus one at 1460-1650m off Browns Bank, and a third group composed of the remaining tows in the two deepest strata. The two shallow Browns Bank sets differed from the larger 'shallow' group (average dissimilarity = $43 \%$ ) due primarily to the presence of Glyptocephalus cynoglossus and the absence of Alepocephalus agassizi and Etmopterus princeps. The average dissimilarity between the two large station groups $(48 \%)$ was due particularly to higher abundance of $C$. fabricii and C. rupestris in the 'shallow' strata and Halosauropsis macrochir and A. agassizi in the deeper strata. For C20, sampling was more intensive and seven groups formed but, nonetheless, there were two main groups, one containing most of the tows in the three shallow strata and another with most of the tows in the two deep strata, analogous to the two main groups in C19. The average dissimilarity between these two groups (49\%) was also comparable to that observed in C19, and was due to the same species except that, in C20, Coryphaenoides spp. replaced $A$. agassizi in importance in the deep strata. In C20, a secondary deep group formed containing two stations that differed from the main deep group (average dissimilarity $=46 \%$ ) due to low catches of Synaphobranchus kaupii and the absence of Aldrovandia spp. and Simenchelys parasitica. The three smaller clusters on the left of the dendrogram are composed largely of tows in the shallowest stratum, and differ variously from the main 'shallow' group by the presence of the upper slope species, G. cynoglossus and Phycis chesteri, and lesser abundance of mid-slope species. Thus, the patterns of species distributions described by the two surveys were in general agreement.

A combined list for the two surveys of the taxa that were among the top 10 numerically within at least one depth stratum (Table 4) illustrates how the predominant species varied with depth. Centroscyllium fabricii, C. rupestris and Nezumia bairdii dominated catches in the three shallowest strata. Alepocephalus agassizii and S. kaupi were moderately abundant in all depths but rose to prominence in rankings in the two deepest strata due primarily to the much reduced abundance, at these depths, of the three species that dominated at shallower depths. The species that actually had their highest abundance in the two deepest strata were H. macrochir, Gaidropsarus ensis, Hydrolagus affinis and Rouleina attrita.

Ranking the top 10 taxa by weight rather than by number replaced four small-bodied taxa ( $S$. parasitica, Coryphaenoides spp., Dicrolene introniger and Aldrovandia spp.) by larger-bodied ones (Centroscymnus coelolepis, Rhinochimaera atlantica, Cottunculus thompsonii and Macrourus berglax) (Table 4). This resulted in differences in rankings, particularly in a substantially higher ranking of Reinhardtius hippoglossoides, but did not materially change the perceptions based on numbers on how the fauna changed with depth. 
Table 3. Demersal species not or seldom recorded previously from the NW Atlantic: number caught $(n)$, capture latitude and longitude, depth (min-max tow depth, m), Atlantic Reference Centre (ARC) catalogue number, and notes. (KU - University of Kansas Natural History Museum, MCZ - Museum of Comparative Zoology, Harvard University, Cambridge, MA., USA.)

Aldrovandia gracilis: $n=10: 41^{\circ} 55^{\prime} \mathrm{N}, 65^{\circ} 19^{\prime} \mathrm{W}-42^{\circ} 48^{\prime} \mathrm{N}, 61^{\circ} 26^{\prime} \mathrm{W}, 1313-1776 \mathrm{~m}$. ARC $26788(n=1)$, ARC $9713153(n=1)$, ARC $9713155(n=3)$, ARC $9713157(n=1)$, ARC $9813168(n=1), 9813171(n=2)$, ARC $9813173(n=1)$. Northern limit previously accepted as Virginia (Sulak, 1990), an unverifiable record from $42^{\circ} 31^{\prime} \mathrm{N}, 63^{\circ} 40^{\prime} \mathrm{W}$ (Roule and Angel, 1933) being regarded as doubtful. Present records lend credence to that of Roule and Angel (1933).

Bathypterois dubius: $n=5$ : four at $42^{\circ} 08^{\prime} \mathrm{N} 65^{\circ} 08^{\prime} \mathrm{W}, 1483-1629 \mathrm{~m}$, ARC 25403; one at $42^{\circ} 33^{\prime} \mathrm{N} 64^{\circ} 12^{\prime} \mathrm{W}, 1183-1203 \mathrm{~m}$, ARC 9914871. Recorded previously from Grand Bank (ARC 9111413) by Templeman (1966) and from Bear Seamount by Moore et al. (2003). Other verified specimens from the vicinity of Bear Seamount are KU 8450, MCZ 165866 (one specimen), and MCZ 167902 (three spec.) (K. Hartel, MCZ, pers. comm.).

Barathrites parri: $n=2$ : one at $42^{\circ} 33^{\prime} \mathrm{N} 63^{\circ} 25^{\prime} \mathrm{W}, 1494-1533 \mathrm{~m}, \mathrm{ARC} 9914912 ; 1$ at $42^{\circ} 39^{\prime} \mathrm{N} 62^{\circ} 25^{\prime} \mathrm{W}, 1384-1423 \mathrm{~m}$, ARC 9914914. Moore et al. (2003) report two specimens from off southern New England.

Cataetyx laticeps: $n=1: 42^{\circ} 39^{\prime} \mathrm{N} 62^{\circ} 25^{\prime} \mathrm{W}, 1384-1423 \mathrm{~m}$, ARC 27729 . Previously reported from off Grand Bank at $42^{\circ} 54^{\prime} \mathrm{N}$, $51^{\circ} 18^{\prime} \mathrm{W}$ (Bänón, 2001) (one specimen), and from the Gulf of Mexico (McEachran and Fechhelm, 1998).

Cetonurus globiceps: $n=1$ : 42 ${ }^{\circ} 07^{\prime} 64^{\circ} 57^{\prime} \mathrm{W}, 1672-1748 \mathrm{~m}$, ARC 27641. Previously reported from the Caribbean - Gulf of Mexico (Geistdoerfer, 1986; Geistdoerfer, 1990; McEachran and Fechhelm, 1998).

Gadomus arcuatus: $n=2$ : one at $42^{\circ} 21^{\prime} \mathrm{N} 64^{\circ} 51^{\prime} \mathrm{W}, 913-1053 \mathrm{~m}$, ARC 27758 ; one at $42^{\circ} 45^{\prime} 62^{\circ} 40^{\prime} \mathrm{W}, 918-1068 \mathrm{~m}$, ARC 27759. Previously reported from the Caribbean, Gulf of Mexico and northeastern coast of South America (Cohen et al., 1990; Geistdoerfer, 1986; Geistdoerfer, 1990; Goode and Bean, 1896; Iwamoto, 2002; McEachran and Fechhelm, 1998).

Coryphaenoides alateralis: $n=1$ : $42^{\circ} 45^{\prime} \mathrm{N} 62^{\circ} 40^{\prime} \mathrm{W}, 918-1068 \mathrm{~m}$, ARC 27678. Only four specimens have been recorded previously (Moore et al., 2003), from the Gulf of Mexico, Hudson Canyon and Bear Seamount (39 $55^{\prime} \mathrm{N} 67^{\circ} 30^{\prime} \mathrm{W}$, two specimens).

Coryphaenoides mediterraneus: $n=4$ : one at $42^{\circ} 08^{\prime} \mathrm{N} 64^{\circ} 56^{\prime} \mathrm{W}, 1670-1772 \mathrm{~m}$, ARC 27752 ; two at $42^{\circ} 51^{\prime} \mathrm{N} 61^{\circ} 24^{\prime} \mathrm{W}$, 1653-1743 m, ARC27640; 1 at 42 $58^{\prime} \mathrm{N} 61^{\circ} 18^{\prime} \mathrm{W}, 1653-1750 \mathrm{~m}$, ARC27744. Previously recorded from the Gulf of Mexico (Geistdoerfer, 1986; Geistdoerfer, 1990; Iwamoto, 2002; McEachran and Fechhelm, 1998).

Guttigadus latifrons: $n=1: 43^{\circ} 50^{\prime} \mathrm{N} 58^{\circ} 20^{\prime} \mathrm{W}, 1682-1820 \mathrm{~m}$, ARC 25404 . This is the first record from the NW Atlantic.

Pachycara crassiceps: $n=2$ : one at $42^{\circ} 27^{\prime} \mathrm{N} 63^{\circ} 33^{\prime} \mathrm{W}, 1646-1664 \mathrm{~m}$. ARC 9914939; one at $42^{\circ} 33^{\prime} \mathrm{N} 63^{\circ} 07^{\prime} \mathrm{W}, 1659-1693 \mathrm{~m}$, ARC 9914940. These are the first records from the NW Atlantic.

Some of the taxa in these comparisons consisted of more than one species, distorting the results to some extent. Nothing can be added to clarify the species composition of Apristurus spp., but it is clear that the Aldrovandia spp. group was largely comprised of Aldrovandia phalacra (Table 2). The bi-modal depth distribution of Coryphaenoides spp. presents a more complex situation. The abundance of specimens taken in the three deepest strata increased with depth, as did their mean length $(12,14$ and $19 \mathrm{~cm})$, and these fish were likely to have been in large part Coryphaenoides carapinus. However, of the 123 specimens caught in the shallowest stratum (mean length $25 \mathrm{~cm}$ ), only one was kept for subsequent laboratory identification and it proved to be Coryphaenoides alateralis, a species not previously reported from the area (see Table 3). This is too weak a basis on which to make an inference about the identity of the remaining specimens in this stratum. It is clear, however, that at least two species of Coryphaenoides, with different depth distributions, were making important contributions to the present collection.

The six tows made off Banquereau Bank that were classed as problem-free were combined into two depth groups, $1100-1460 \mathrm{~m}$ and $1460-1830 \mathrm{~m}$, for data presentation (Table 5). Alepocephalus bairdii and R. attrita were prominent components of these catches, and $C$. rupestris and $C$. fabricii were less dominant than elsewhere. However, such differences from the more western sampling areas are as likely to be due to the vagaries of sampling in this area as to differences in faunal composition. 
HALLIDAY et al.: Demersal Fish Fauna off Nova Scotia, Canada, from Surveys in 1994-95.
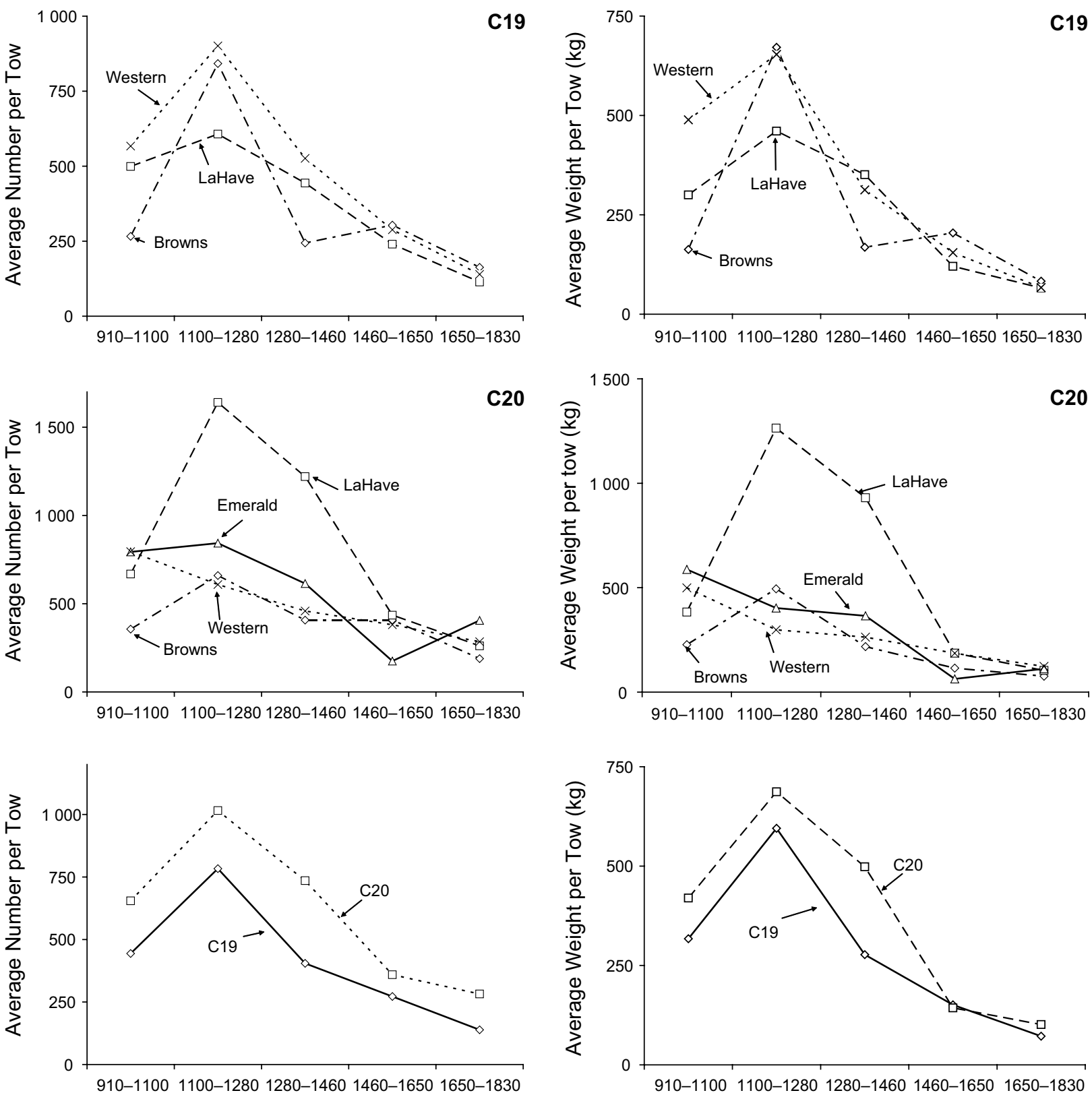

\section{Depth Stratum (m)}

Fig. 2. Average catch rates of demersal species by number and weight for each sampling area by depth stratum for C19 (top panels) and C20 (mid-panels) and by survey overall (bottom panels). (Banquereau Bank data excluded; averages for $1460-1650 \mathrm{~m}$ and $1650-1830 \mathrm{~m}$ strata adjusted by x1.25 and x1.33 respectively - see text; scales for Y-axes vary.)

\section{Size compositions}

Total length, the measurement used for all species on the Cape Chidley surveys, is not the preferred metric for those species with fragile tails that are easily damaged during capture, e.g. Macrouridae and Chimaeriformes, e.g. ICES (2008). However, the conclusions made here from comparisons of size compositions between surveys and depth strata are relative, and conclusions are not likely to be affected by whatever bias the use of total length may have introduced.

Area-weighted length frequencies, indicative of the length compositions of the populations available to 

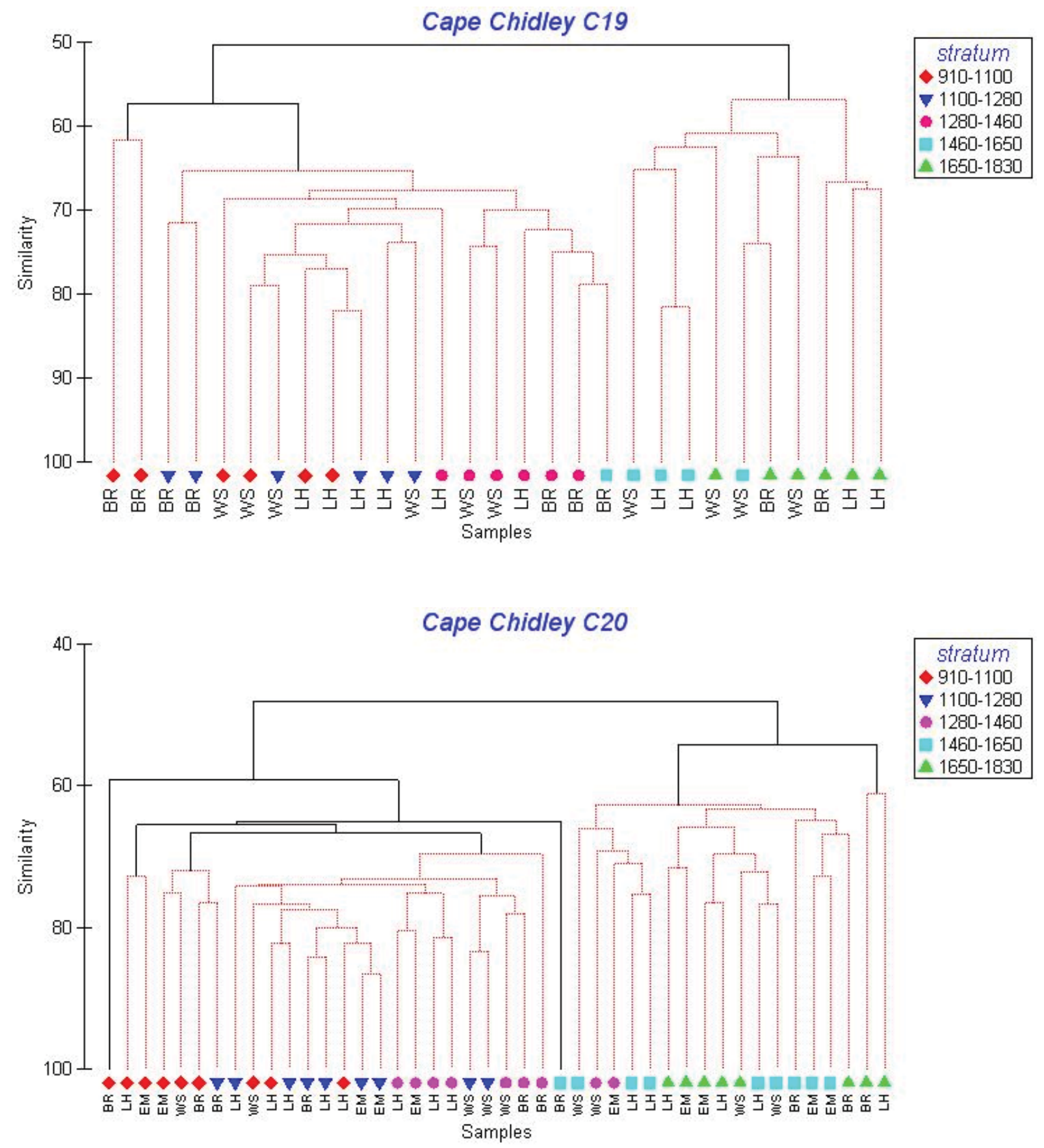

Fig. 3. Hierarchical clustering using fourth-root transformation of catch numbers for all species and stations from Cape Chidley cruises C19 (top panel) and C20 (bottom panel). (Letters indicate banks: BR- Browns; LH-LaHave; EM-Emerald; WS Western). Symbols indicate depth strata in metres (see key on right). 
the gear, were generally similar between surveys for the five species that contributed most, by weight, to catches (Fig. 4). For R. hippoglossoides and Harriotta raleighana, the relative numbers by length group were almost identical between surveys. In the other three cases, C. rupestris, C. fabricii and A. agassizii, population estimates from $\mathrm{C} 19$ contained fewer small fish than did those from $\mathrm{C} 20$. The $\mathrm{C} 19$ estimates of large specimens of C. rupestris were lower also, and total population number was $60 \%$ of that for $\mathrm{C} 20$. In the cases of $C$. fabricii and A. agassizii, population number estimates from $\mathrm{C} 19$ were $85 \%$ and $70 \%$ respectively, of those from C20.

For these five species, the size of fish caught varied with depth in most cases (Fig. 5). Typically, average lengths were smallest in the shallowest tows, increasing with depth to the 1280-1460 m stratum or to the 1460-1650 m stratum. Catches in the deepest stratum suggested a levelling off in average size but catch numbers in this stratum were so few that any conclusion is speculative. The clearest example of increasing size with depth is provided by $R$. hippoglossoides, average lengths in 910-1100 m being about $60 \mathrm{~cm}$, increasing to about 65 $\mathrm{cm}$ in $1100-1280 \mathrm{~m}$ and $65-70 \mathrm{~cm}$ in $1280-1650 \mathrm{~m}$, and trends for $C$. rupestris and $A$. agassizii were roughly similar in scale. In contrast, the size of $C$. fabricii showed only a slight tendency to increase with depth and $H$. raleighana showed none, average length being lowest at the middle of the depth range sampled.

\section{Pelagic Species}

The Cape Chidley bottom trawl surveys caught at least 40 taxa of pelagic fishes, consisting of approximately 1500 specimens weighing almost $60 \mathrm{~kg}$ (Table 6). There were cases of catches reported at a taxonomic level higher than species for pelagic taxa also and, for a number of these, voucher specimens were available that give an indication of their species composition (Table 7). However, the data from these voucher specimens are too scant to allow inferences to be made about the relative abundance of these species in catches.

The survey reported on by Markle et al. (1988), conducted in 1984 by the government-chartered vessel, Lady Hammond, using a Western IIA bottom otter trawl, similarly caught about 40 taxa of pelagic fishes, consisting of almost 1000 specimens (Table 8). Included in Table 8 are three species of liparid, and the trichiurid Benthodesmus tenuis, species that would be considered demersal under present criteria, but presumably were considered pelagic by Markle et al. (1988).

There was a strong similarity in the pelagic taxa caught by bottom trawl on the two surveys, about $70 \%$ being in common, despite differences in gear design and depths fished, and most of these taxa occurred also in midwater trawl samples from the same area (Themelis and Halliday, 2012), or in waters to the immediate southwest of the sampling area (Moore et al., 2003). Of note, however, is the record of Platytroctes apus (Cape Chidley, $42^{\circ} 45^{\prime} \mathrm{N}$ 61 $1^{\circ} 41^{\prime} \mathrm{W}, 1498-1522 \mathrm{~m}$, ARC 9914821), only two specimens of which have been reported previously from the NW Atlantic, one at about $40^{\circ} \mathrm{N}$ (Hartel et al., 2008), the other off Greenland ((Møller et al., 2010), and the record of Benthodesmus tenuis (Lady Hammond, 42 $57^{\circ} \mathrm{N}$ $61^{\circ} 41^{\prime} \mathrm{W}, 558-585 \mathrm{~m}, \mathrm{ARC} 8600838$ ), which is only the second record north of Cape Hatteras, the first being off Browns Bank (Scott and Scott, 1988).

\section{Discussion}

The reason why the number of benthic taxa caught per tow differed between surveys, being about $15 \%$ higher on $\mathrm{C} 20$ than on $\mathrm{C} 19$, is not clear. The surveys were quasicommercial in character, and close cooperation between ship's crew and scientific personnel was required to meet the needs of both. It is possible that this cooperation improved between surveys, explaining the higher number of taxa per tow observed on C20. It is also possible, however, that minor differences in the trawl nets, the net used on C19 being lost at sea and replaced on C20 with another built to the same specifications, contributed to this, and other, differences in results between surveys.

The much higher catches of $C$. rupestris in the LaHave area than in other areas on C20 occurred, in large part, in a series of tows added at the end of the sampling program. It is possible that these tows did not conform to the randomized sampling design, biasing results. Nonetheless, when these added tows are disregarded, abundance estimates for this species in the LaHave area, although reduced, remain higher than in other areas. In contrast, C19 estimates of $C$. rupestris in the LaHave area were not higher than elsewhere. However, sampling on C19 was restricted to non-contiguous blocks, which could have introduced bias to abundance estimates from this survey if, for example, areas of high density of $C$. rupestris were excluded from the sampling blocks. An association of C. rupestris with canyons, as has been noted by Snelgrove and Haedrich (1985) in data from southeastern Grand Bank and off New England, could underlie such a bias. While there is no evidence for such an association in data from the present study, differences in sampling design nonetheless may have been an important factor causing variability in quantities caught between surveys.

While areas fished differed to some extent between surveys, cluster analysis did not find area to be a factor of importance in determining species composition; rather it was depth that had an over-riding influence. Catch rates were high in the three shallowest strata $(910-1460 \mathrm{~m})$ but declined to much lower levels in 1460-1650 $\mathrm{m}$ and to minima in 1650-1830 $\mathrm{m}$ on both surveys. In the present 
Table 4. Demersal species abundance (by number, and weight, per tow) and dominance (ranking) within depth strata. (Banquereau Bank data excluded. A: 910-1100 m, B: 1100-1280 m, C: 1280-1460 m, D: 1460-1650 m, E: 1650-1830 m. $\mathbf{D}$ and $\mathbf{E}$ adjusted by $x 1.25$ and $x 1.33$, respectively. + denotes $<0.5 /$ tow.)

\begin{tabular}{|c|c|c|c|c|c|c|c|c|c|c|}
\hline \multirow[b]{2}{*}{ Depth stratum } & \multicolumn{5}{|c|}{ Average/tow } & \multicolumn{5}{|c|}{ Ranking } \\
\hline & $\mathbf{A}$ & B & $\mathbf{C}$ & D & $\mathbf{E}$ & $\mathbf{A}$ & B & $\mathbf{C}$ & D & $\mathbf{E}$ \\
\hline Number of tows & 15 & 15 & 15 & 14 & 14 & 15 & 15 & 15 & 14 & 14 \\
\hline \multicolumn{11}{|l|}{ A. By number } \\
\hline Centroscyllium fabricii & 327 & 281 & 98 & 20 & 4 & 1 & 2 & 2 & 5 & - \\
\hline Coryphaenoides rupestris & 74 & 330 & 201 & 28 & 8 & 2 & 1 & 1 & 3 & 6 \\
\hline Nezumia bairdii & 53 & 71 & 68 & 18 & 4 & 3 & 3 & 4 & 6 & - \\
\hline Synaphobranchus kaupii & 36 & 46 & 68 & 49 & 31 & 4 & 5 & 5 & 2 & 3 \\
\hline Harriotta raleighana & 17 & 17 & 15 & 9 & 5 & 5 & 8 & 6 & - & 9 \\
\hline Alepocephalus agassizii & 15 & 55 & 89 & 98 & 56 & 6 & 4 & 3 & 1 & 1 \\
\hline Reinhardtius hippoglossoides & 13 & 14 & 9 & 1 & 1 & 7 & 9 & 8 & - & - \\
\hline Apristurus spp. & 12 & 24 & 7 & 3 & 3 & 8 & 7 & 10 & - & - \\
\hline Simenchelys parasitica & 9 & 4 & 4 & 5 & 3 & 9 & - & - & - & - \\
\hline Coryphaenoides spp. & 9 & 0 & 2 & 21 & 33 & 10 & - & - & 4 & 2 \\
\hline Etmopterus princeps & 5 & 27 & 4 & 1 & 1 & - & 6 & - & - & - \\
\hline Dicrolene introniger & 2 & 9 & 5 & 4 & + & - & 10 & - & - & - \\
\hline Antimora rostrata & 7 & 6 & 13 & 11 & 7 & - & - & 7 & 9 & 8 \\
\hline Aldrovandia spp. & 1 & 6 & 8 & 14 & 4 & - & - & 9 & 7 & - \\
\hline Rouleina attrita & + & + & 2 & 13 & 8 & - & - & - & 8 & 7 \\
\hline Halosauropsis macrochir & + & + & + & 9 & 17 & - & - & - & 10 & 4 \\
\hline Gaidropsarus ensis & + & + & 1 & 9 & 13 & - & - & - & - & 5 \\
\hline Hydrolagus affinis & + & + & 1 & 1 & 4 & - & - & - & - & 10 \\
\hline \multicolumn{11}{|l|}{ B. By weight $(\mathrm{kg})$} \\
\hline Centroscyllium fabricii & 242 & 206 & 74 & 14 & 3 & 1 & 2 & 2 & 3 & - \\
\hline Reinhardtius hippoglossoides & 30 & 38 & 30 & 6 & 3 & 2 & 3 & 4 & 8 & - \\
\hline Coryphaenoides rupestris & 25 & 237 & 177 & 26 & 6 & 3 & 1 & 1 & 2 & 6 \\
\hline Harriotta raleighana & 22 & 20 & 17 & 10 & 7 & 4 & 7 & 5 & 4 & 3 \\
\hline Apristurus spp. & 18 & 38 & 9 & 4 & 1 & 5 & 4 & 7 & 10 & - \\
\hline Centroscymnus coelolepis & 15 & 22 & 7 & 3 & 1 & 6 & 6 & 9 & - & - \\
\hline Rhinochimaera atlantica & 14 & 9 & 1 & 1 & 1 & 7 & 9 & - & - & - \\
\hline Cottunculus thompsonii & 7 & 4 & 3 & + & 0 & 8 & - & - & - & - \\
\hline Synaphobranchus kaupii & 5 & 7 & 12 & 7 & 4 & 9 & 10 & 6 & 5 & 8 \\
\hline Etmopterus princeps & 4 & 28 & 4 & 1 & + & 10 & 5 & - & - & - \\
\hline Alepocephalus agassizii & 3 & 14 & 46 & 38 & 18 & - & 8 & 3 & 1 & 1 \\
\hline Antimora rostrata & 4 & 3 & 7 & 7 & 5 & - & - & 8 & 6 & 7 \\
\hline Nezumia bairdii & 3 & 6 & 7 & 1 & 1 & - & - & 10 & - & - \\
\hline Rouleina attrita & + & + & + & 6 & 3 & - & - & - & 7 & 10 \\
\hline Hydrolagus affinis & 1 & 2 & 6 & 5 & 11 & - & - & - & 9 & 2 \\
\hline Halosauropsis macrochir & + & + & + & 4 & 6 & - & - & - & - & 4 \\
\hline Gaidropsarus ensis & + & + & 1 & 4 & 6 & - & - & - & - & 5 \\
\hline Macrourus berglax & 3 & 4 & 2 & 4 & 3 & - & - & - & - & 9 \\
\hline
\end{tabular}


Table 5. Demersal species abundance (by number, and weight, per tow) and dominance (ranking) within depth strata in the Banquereau Bank area. (Deep strata adjusted as in Table 4. + denotes $<0.5 /$ tow.)

\begin{tabular}{|c|c|c|c|c|}
\hline \multirow[b]{2}{*}{ Depth Strata } & \multicolumn{2}{|c|}{ Average/tow } & \multicolumn{2}{|c|}{ Ranking } \\
\hline & $1100-1460 \mathrm{~m}$ & $1460-1830 \mathrm{~m}$ & $1100-1460 \mathrm{~m}$ & $1460-1830 \mathrm{~m}$ \\
\hline Number of tows & 3 & 3 & 3 & 3 \\
\hline \multicolumn{5}{|l|}{ A. By number } \\
\hline Nezumia bairdii & 32 & 12 & 1 & 5 \\
\hline Coryphaenoides rupestris & 32 & 22 & 2 & 4 \\
\hline Alepocephalus bairdii & 20 & + & 3 & - \\
\hline Rouleina attrita & 16 & 115 & 4 & 1 \\
\hline Synaphobranchus kaupii & 15 & 24 & 5 & 3 \\
\hline Centroscyllium fabricii & 10 & 0 & 6 & - \\
\hline Alepocephalus agassizii & 8 & 98 & 7 & 2 \\
\hline Harriotta raleighana & 6 & 5 & 8 & 10 \\
\hline Antimora rostrata & 5 & 11 & 9 & 6 \\
\hline Reinhardtius hippoglossoides & 5 & 2 & 10 & - \\
\hline Halosauropsis macrochir & + & 9 & - & 7 \\
\hline Bathysaurus ferox & 0 & 9 & - & 8 \\
\hline Macrouridae & 1 & 7 & - & 9 \\
\hline \multicolumn{5}{|l|}{ B. By weight (kg) } \\
\hline Alepocephalus bairdii & 64 & 2 & 1 & - \\
\hline Coryphaenoides rupestris & 18 & 6 & 2 & 8 \\
\hline Reinhardtius hippoglossoides & 14 & 7 & 3 & 6 \\
\hline Harriotta raleighana & 11 & 12 & 4 & 3 \\
\hline Centroscyllium fabricii & 9 & 0 & 5 & - \\
\hline Hydrolagus affinis & 8 & 6 & 6 & 9 \\
\hline Alepocephalus agassizii & 5 & 141 & 7 & 1 \\
\hline Nezumia bairdii & 4 & 2 & 8 & - \\
\hline Rouleina attrita & 4 & 62 & 9 & 2 \\
\hline Antimora rostrata & 4 & 8 & 10 & 5 \\
\hline Bathyraja sp. & 3 & 10 & - & 4 \\
\hline Bathysaurus ferox & 0 & 6 & - & 7 \\
\hline Narcetes stomias & 0 & 5 & - & 10 \\
\hline
\end{tabular}

study, it was necessary to apply correction factors to catches to account for a reduction in towing speed, and hence distance towed, when fishing in the two deepest strata, but their adequacy is not known. An inference about the affects of this difference in sampling procedure with depth can be made based on catches of several large-bodied species that are perhaps the most capable of avoiding slowmoving nets. According to Moore et al. (2003), the depth distribution of $H$. raleighana extends to $2452 \mathrm{~m}$, that of C.coelolepis to $3675 \mathrm{~m}$, and of E. princeps to $2213 \mathrm{~m}$, but these species were caught by the Cape Chidley primarily in 910-1460 m. This suggests that, relative to catches in these strata, catches in the two deepest strata may have underestimated abundance of these, and perhaps other, species. Nonetheless, these particular species were not among the most important in determining the dissimilarity between the two main groups and, despite the confounding effect of changes in fishing procedure with depth, present results are consistent with those of other studies which have found a distinction between mid slope and lower slope assemblages. In particular, cluster analysis of fish occurrence data from a video survey at $53^{\circ}-56^{\circ} \mathrm{W}$ (Baker 

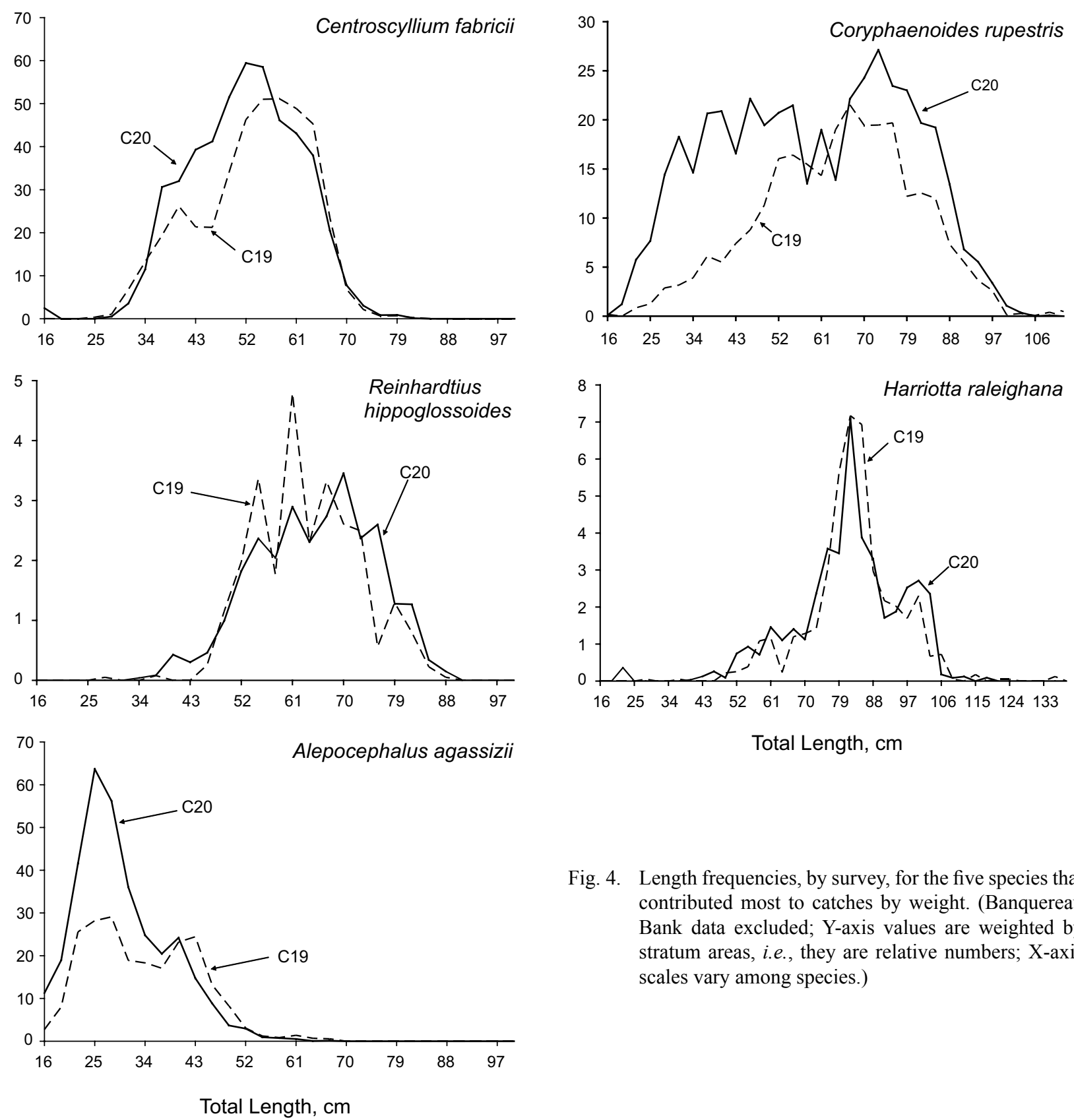

Fig. 4. Length frequencies, by survey, for the five species that contributed most to catches by weight. (Banquereau Bank data excluded; Y-axis values are weighted by stratum areas, i.e., they are relative numbers; $\mathrm{X}$-axis scales vary among species.)

et al., 2012), immediately to the east of the present surveys, defined a boundary between species assemblages at about $1300 \mathrm{~m}$, and these authors cite other such cases.

The bottom trawl survey off Nova Scotia by the Lady Hammond (Markle et al., 1988) extended from LaHave Bank to St. Pierre Bank $\left(56^{\circ} \mathrm{W}\right)$ and thus overlapped strongly, geographically, with the Cape Chidley surveys. Depths surveyed by the Lady Hammond extended from $400 \mathrm{~m}$ to $1200 \mathrm{~m}$ and thus catches contained many upper slope species that were not available to Cape Chidley

surveys. However, in those depth strata that overlapped (strata 3+4: 800-1200 m of Markle et al. (1988), their Table 5, versus 910-1280 m, present data), the species predominating in catches were similar. However, in these overlapping strata, the Cape Chidley caught more than five times the number, and ten times the weight, per tow of the Lady Hammond (all taxa combined), and caught almost twice as many species per tow. The Western IIa net used by Markle et al. (1988) was smaller than the Engel trawl used by the Cape Chidley (headline height $4.6 \mathrm{~m}$, wingspread $10.7 \mathrm{~m}$ (Carrothers, 1988) versus $6.0 \mathrm{~m}$ and 

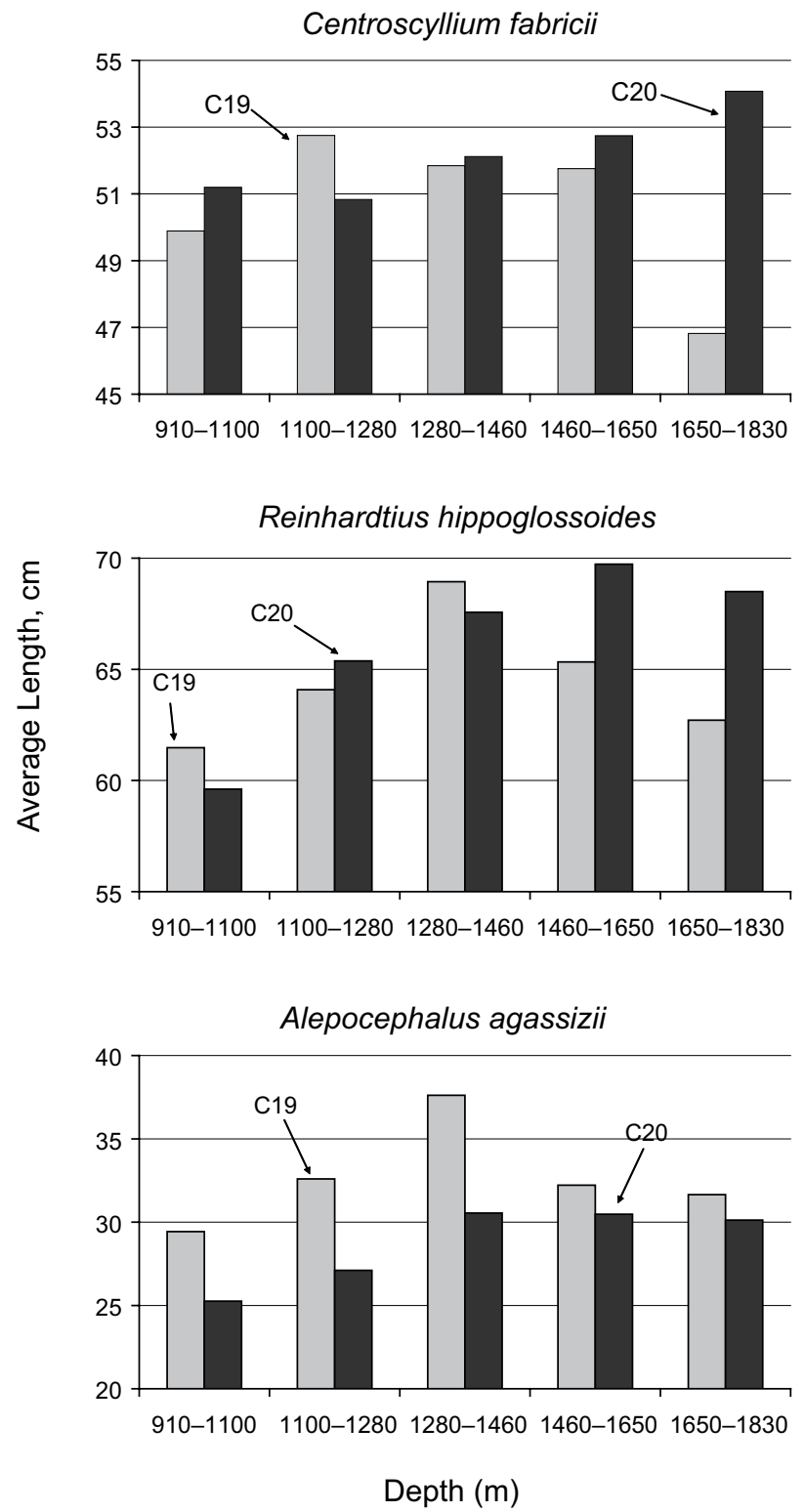

$24 \mathrm{~m}$, respectively) and nominal tow time was half as long. These factors likely account for much of the difference in catches. Also, however, the Lady Hammond was fishing at the limit of its capability at these depths, a factor that likely reduced further its fishing power relative to the Cape Chidley.

The video survey of Baker et al. (2012) of the fish fauna in canyons off SW Newfoundland in 350-2250 m provided a list of species observed that was very similar to the lists of species caught by the Lady Hammond and Cape Chidley at comparable sampling depths. There were differences in the relative importance of these species between trawl and video surveys which could reflect differences in gear selection or sampling design, e.g. restriction of video sampling to canyons.
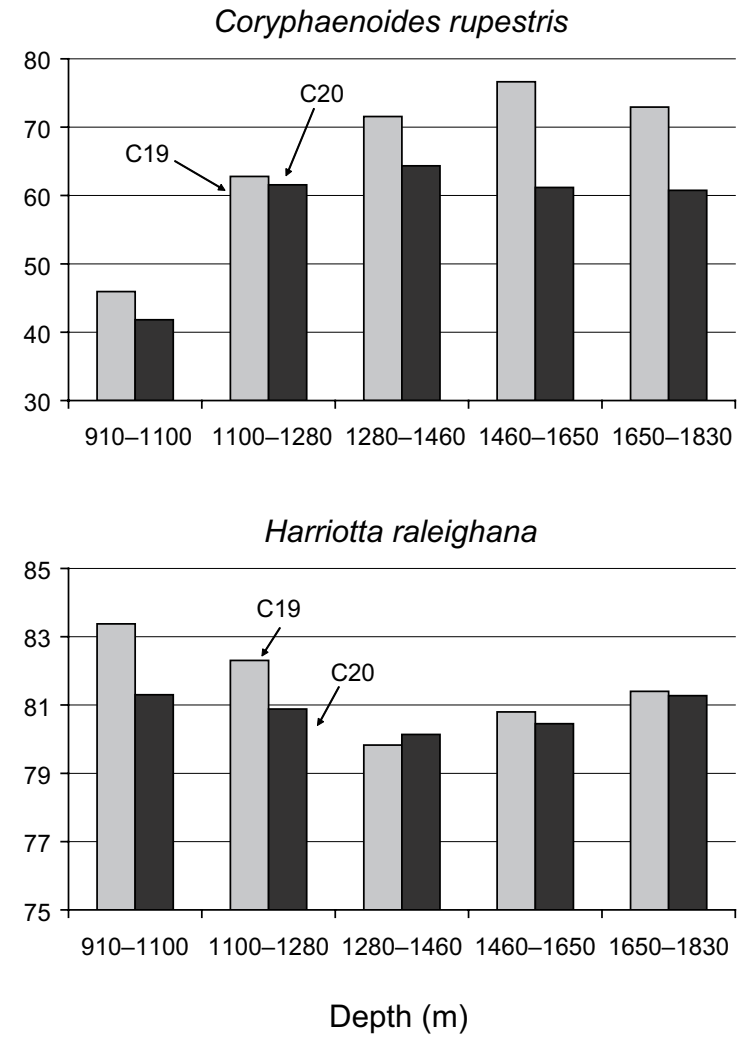

Fig. 5. Average lengths by depth stratum (m), by survey, for the five species that contributed most to catches by weight. (Banquereau Bank data excluded; note that Y-axis scales vary.)

Markle et al. (1988) found the slope fauna off Nova Scotia to have many similarities with the temperate fauna of the Mid-Atlantic Bight, i.e. the area from south of Georges Bank to Cape Hatteras, as characterized by Sulak (1982). Other descriptions of that fauna are given by Markle and Musick (1974) and Haedrich et al. (1975). Markle et al. (1988) did, however, note substantial differences between the Scotian Slope fauna and that off southeastern Grand Bank (Snelgrove and Haedrich, 1985) in terms of dominant species, diversity and depth distributions. Pinhorn and Halliday (1997) subsequently proposed, based on research vessel trawl surveys conducted in 1949-91, that The Tail of Grand Bank (about $51^{\circ} \mathrm{W}$ ) was a boundary of importance to the distribution of slope fish species, 'northern' species occurring at reduced densities (and/or at greater depth) to the west and 'southern' species 
Table 6. Pelagic taxa, Cape Chidley exploratory fishing 1994-95: number caught (No.) and number of occurrences (Occur.) by taxon. ((1) - see Table 7 for supplementary information on species composition.)

\begin{tabular}{|c|c|c|c|}
\hline Order/Family & Species (or lowest taxon) & No. & Occur. \\
\hline \multicolumn{4}{|l|}{ Anguilliformes } \\
\hline Derichthyidae & Derichthys serpentinus & 1 & 1 \\
\hline Nemichthyidae & Nemichthys scolopaceus & 117 & 50 \\
\hline Serrivomeridae & Serrivomer beanii & 294 & 77 \\
\hline \multicolumn{4}{|c|}{ Saccopharyngiformes } \\
\hline Eurypharyngidae & Eurypharynx pelecanoides & 17 & 12 \\
\hline \multicolumn{4}{|l|}{ Osmeriformes } \\
\hline Bathylagidae & Bathylagus euryops & 65 & 29 \\
\hline \multirow[t]{3}{*}{ Platytroctidae } & Holtbyrnia anomala & 1 & 1 \\
\hline & Maulisia microlepis & 4 & 4 \\
\hline & Platytroctes apus & 1 & 1 \\
\hline \multicolumn{4}{|l|}{ Stomiiformes } \\
\hline \multirow[t]{2}{*}{ Gonostomatidae } & Sigmops bathyphilus & 9 & 8 \\
\hline & Sigmops elongatum & 15 & 14 \\
\hline \multirow[t]{2}{*}{ Sternoptychidae } & Argyropelecus aculeatus & 10 & 9 \\
\hline & Argyropelecus gigas & 2 & 2 \\
\hline \multirow[t]{6}{*}{ Stomiidae } & Borostomias antarcticus & 6 & 5 \\
\hline & Chauliodus sloani & 101 & 48 \\
\hline & Stomias boa ferox & 67 & 38 \\
\hline & Melanostomias bartonbeani & 3 & 3 \\
\hline & Malacosteus niger & 8 & 7 \\
\hline & Stomiiformes NS & 6 & 4 \\
\hline \multicolumn{4}{|l|}{ Aulopiformes } \\
\hline Paralepididae & Paralepididae NS (1) & 13 & 13 \\
\hline Anotopteridae & Anotopterus pharao & 3 & 3 \\
\hline \multirow[t]{2}{*}{ Alepisauridae } & Alepisaurus ferox & 6 & 6 \\
\hline & Alepisaurus brevirostris & 3 & 3 \\
\hline \multicolumn{4}{|l|}{ Myctophiformes } \\
\hline Myctophidae & Myctophidae NS (1) & 546 & 68 \\
\hline \multicolumn{4}{|l|}{ Lophiiformes } \\
\hline Melanocetidae & Melanocetus spp. (1) & 5 & 5 \\
\hline Himantolophidae & Himantolophus albinares & 2 & 2 \\
\hline Ceratiidae & Cryptopsaras couesii & 4 & 3 \\
\hline Gigantactinidae & Gigantactis vanhoeffeni & 3 & 3 \\
\hline \multicolumn{4}{|l|}{ Beloniformes } \\
\hline Scomberesocidae & Scomberesox saurus & 1 & 1 \\
\hline \multicolumn{4}{|c|}{ Stephanoberyciformes } \\
\hline Melamphaidae & Melamphaidae NS (1) & 91 & 43 \\
\hline \multicolumn{4}{|l|}{ Cetomimiformes } \\
\hline Rondeletiidae & Rondeletia loricata & 3 & 4 \\
\hline Cetomimidae & Cetostoma regani & 1 & 1 \\
\hline
\end{tabular}


HALLIDAY et al.: Demersal Fish Fauna off Nova Scotia, Canada, from Surveys in 1994-95.

Table 6. (Continued).

\begin{tabular}{|c|c|c|c|}
\hline Order/Family & Species (or lowest taxon) & No. & Occur \\
\hline \multicolumn{4}{|l|}{ Beryciformes } \\
\hline Anoplogastridae & Anoplogaster cornuta & 18 & 16 \\
\hline \multicolumn{4}{|l|}{ Perciformes } \\
\hline Howellidae & Howella brodiei & 28 & 14 \\
\hline Caristiidae & Caristius sp. & 1 & 1 \\
\hline \multirow[t]{2}{*}{ Chiasmodontidae } & Chiasmodon sp. & 25 & 21 \\
\hline & Pseudoscopelus sp. & 3 & 3 \\
\hline Zoarcidae & Melanostigma atlanticum & 2 & 1 \\
\hline
\end{tabular}

occurring in lesser abundance to the east. This was attributed to the influence of the cold Labrador Current, which bathes northeastern slopes with water less than $4^{\circ} \mathrm{C}$ to depths of at least $1000 \mathrm{~m}$ but turns offshore at about this location. However, their data for southern Grand Bank and west was restricted very largely to upper slope depths.

Direct comparisons of faunal composition and species abundances obtained from present data with those from previous surveys at similar depths are confounded by differences in survey design and by the large differences in gear size and vessel fishing power. The differences in vessels and gears used are particularly pertinent to comparisons with those surveys in the Mid Atlantic Bight that used shrimp trawls (Markle and Musick, 1974; Haedrich et al., 1975; Haedrich et al., 1980; Sulak, 1982). These trawls were substantially smaller (headline height of about $2.0 \mathrm{~m}$ ) than that used in present surveys and they were towed at half the speed (1.5 knots). Testimony to a difference in fishing capability is provided by the Cape Chidley captures of large mobile species, which would have the greatest capability for avoidance of small slowmoving nets. While Chimaeriformes and sharks comprise a third of numbers and almost half the weight caught on Cape Chidley surveys, these taxa were of minor to no importance in Mid-Atlantic Bight survey catches, and this must surely be an effect of sampling.

In areas to the north and east of the present study area (NAFO Subareas 2-3), the existence of substantial populations of C. rupestris (Atkinson, 1995), $R$. hippoglossoides (Bowering and Brodie, 1995) and M. berglax (Murua et al., 2005) has been well established. Present data show that a substantial population of C. rupestris occurs also on the Scotian Slope and that it is a dominant member of the upper - mid slope fauna in that area. Pinhorn (1976) cites an observation of spawning and post-spawning fish "off Nova Scotia", and sexually maturing fish have been observed in the area by one of the present authors (DET). The size at
Table 7. Pelagic taxa, Cape Chidley exploratory fishing 1994-1995: supplementary information on the species contributing to cases where taxa are grouped at genus or family level, from laboratory identifications of retained specimens (except Myctophidae includes at-sea identifications also). (No. - the number of specimens identified.)

\begin{tabular}{llr}
\hline Taxon & Species & No. \\
\hline Paralepididae NS & Magnisudis atlantica & 1 \\
Myctophidae NS & Benthosema glaciale & 140 \\
& Ceratoscopelus maderensis & 3 \\
& Lampadena speculigera & 3 \\
& Lampanyctus macdonaldi & 24 \\
Melanocetus spp. & Melanocetus johnsonii & 1 \\
& Melanocetus murrayi & 2 \\
Melamphaidae NS & Poromitra crassiceps & 4 \\
& Scopelogadus beanii & 6 \\
& Scopelogadus mizolepis & 1 \\
\hline
\end{tabular}

sexual maturation of this species in more northern areas is $40-50 \mathrm{~cm}$ (Atkinson, 1995). Thus, the occurrence in present catches of substantial numbers of $C$. rupestris in the length range 15-40 cm supports a view that the species resides within the surveyed area throughout its life cycle. Reinhardtius hippoglossoides was of moderate abundance in Scotian Shelf slope catches, but nonetheless ranked fourth by weight as all catches were of large fish $(>40 \mathrm{~cm})$. This suggests that they were progeny of a more northern spawning population, perhaps that in the Gulf of St. Lawrence (Bowering, 1983). The contribution of $M$. berglax to present catches was minor. Thus, the data for M. berglax and R. hippoglossoides are consistent with The Tail of Grand Bank being of some biogeographic importance, but there is no clear support for this in the case 
Table 8. Pelagic taxa, Lady Hammond bottom trawling 1984: number caught (No.) and number of occurrences (Occur.) by taxon.

\begin{tabular}{|c|c|c|c|}
\hline Order/Family & Species (or lowest taxon) & No. & Occur. \\
\hline \multicolumn{4}{|l|}{ Anguilliformes } \\
\hline Derichthyidae & Nessorhamphus ingolfianus & 5 & 5 \\
\hline Nemichthyidae & Nemichthys scolopaceus & 90 & 27 \\
\hline Serrivomeridae & Serrivomer beanii & 89 & 22 \\
\hline \multicolumn{4}{|c|}{ Saccopharyngiformes } \\
\hline Eurypharyngidae & Eurypharynx pelecanoides & 3 & 3 \\
\hline \multicolumn{4}{|l|}{ Osmeriformes } \\
\hline \multirow[t]{3}{*}{ Bathylagidae } & Bathylagus euryops & 17 & 4 \\
\hline & Bathylagus sp. & 59 & 15 \\
\hline & Melanolagus bericoides & 1 & 1 \\
\hline \multicolumn{4}{|l|}{ Stomiiformes } \\
\hline \multirow[t]{2}{*}{ Gonostomatidae } & Cyclothone sp. & 3 & 2 \\
\hline & Gonostoma elongatum & 47 & 16 \\
\hline \multirow[t]{3}{*}{ Sternoptychidae } & Argyropelecus aculeatus & 7 & 6 \\
\hline & Polyipnus clarus & 9 & 3 \\
\hline & Sternoptyx diaphana & 4 & 4 \\
\hline \multirow[t]{6}{*}{ Stomiidae } & Chauliodus sloani & 143 & 27 \\
\hline & Stomias boa ferox & 123 & 25 \\
\hline & Melanostomias bartonbeani & 1 & 1 \\
\hline & Malacosteus niger & 9 & 7 \\
\hline & Photostomias guernei & 2 & 2 \\
\hline & Stomiiformes NS & 2 & 2 \\
\hline \multicolumn{4}{|l|}{ Aulopiformes } \\
\hline Paralepididae & Paralepididae NS & 26 & 12 \\
\hline \multicolumn{4}{|l|}{ Myctophiformes } \\
\hline \multirow[t]{7}{*}{ Myctophidae } & Benthosema glaciale & 89 & 16 \\
\hline & Ceratoscopelus maderensis & 59 & 10 \\
\hline & Lampanyctus sp. & 15 & 7 \\
\hline & Lampadena sp. & 3 & 3 \\
\hline & Myctophum punctatum & 23 & 4 \\
\hline & Notoscopelus sp. & 14 & 3 \\
\hline & Myctophidae NS & 8 & 2 \\
\hline \multicolumn{4}{|l|}{ Gadiformes } \\
\hline Moridae & Moridae NS & 1 & 1 \\
\hline Melanonidae & Melanonus zugmayeri & 3 & 3 \\
\hline \multicolumn{4}{|l|}{ Lophiformes } \\
\hline Gigantactinidae & Gigantactis vanhoeffeni & 1 & 1 \\
\hline \multicolumn{4}{|l|}{ Beloniformes } \\
\hline Scomberesocidae & Scomberesox saurus & 1 & 1 \\
\hline \multicolumn{4}{|c|}{ Stephanoberyciformes } \\
\hline \multirow[t]{3}{*}{ Melamphaidae } & Melamphaes suborbitalis & 1 & 1 \\
\hline & Poromitra sp. & 6 & 5 \\
\hline & Scopelogadus sp. & 104 & 8 \\
\hline \multicolumn{4}{|l|}{ Cetomimiformes } \\
\hline Rondeletiidae & Rondeletia loricata & 1 & 1 \\
\hline \multicolumn{4}{|l|}{ Beryciformes } \\
\hline Anoplogasteridae & Anoplogaster cornuta & 2 & 2 \\
\hline \multicolumn{4}{|l|}{ Scorpaeniformes } \\
\hline Liparidae & Paraliparis calidus & 1 & 1 \\
\hline
\end{tabular}


HALLIDAY et al.: Demersal Fish Fauna off Nova Scotia, Canada, from Surveys in 1994-95.

Table 8. (Continued).

\begin{tabular}{|c|c|c|c|}
\hline Order/Family & Species (or lowest taxon) & No. & Occur. \\
\hline & Paraliparis copei & 2 & 2 \\
\hline & Paraliparis garmani & 3 & 2 \\
\hline \multicolumn{4}{|l|}{ Perciformes } \\
\hline Howellidae & Howella brodiei & 5 & 5 \\
\hline Caristiidae & Caristius sp. & 1 & 1 \\
\hline Chiasmodontidae & Chiasmodon sp. & 4 & 3 \\
\hline Zoarcidae & Melanostigma atlanticum & 8 & 3 \\
\hline Trichiuridae & Benthodesmus tenuis & 1 & 1 \\
\hline
\end{tabular}

of C. rupestris. Kulka (2006) identified the Laurentian Channel, immediately adjacent to the Scotian Shelf slope, as the pupping area for $C$. fabricii, and the high catches in present surveys are consistent with the survey area being the centre of the species distribution.

\section{Acknowledgements}

This project was jointly funded by National Sea Products Limited (now High Liner Foods Limited), Lunenburg, Nova Scotia, and by the Canadian Department of Fisheries and Oceans (DFO) through Contribution Agreement No. FP280-4-5353/VB4-07/A94-SF353 of the Atlantic Fisheries Adjustment Programme (DFO scientific authority - R. G. Halliday). At-sea data collection was conducted by HMSC under contract to National Sea Products Limited. The authors are particularly grateful to G. Pohle, HMSC, who managed the field sampling programme, to C. Chambers (then of HMSC), who supervised data collection during the March 1995 survey, and to our collaborators at National Sea Products. We thank D. Kulka, Northwest Atlantic Fisheries Centre, St. John's, Newfoundland and G. Pohle for reviews of an earlier draft.

\section{References}

ATKINSON, D. B. 1995. The biology and fishery of roundnose grenadier (Coryphaenoides rupestris Gunnerus, 1765) in the Northwest Atlantic. In: Deep-water fisheries of the North Atlantic oceanic slope. A. G. Hopper, (ed.). Kluwer Academic Publishers, p. 51-111.

BAKER, K. D., R. L. HAEDRICH, P. V. R. SNELGROVE, V. E. WAREHAM, E. N. EDINGER and K. D GILKINSON. 2012. Small-scale patterns of deep-sea fish distributions and assemblages of the Grand Banks, Newfoundland continental slope. Deep-Sea Research I, 65: 171-188. http://dx.doi. org/10.1016/j.dsr.2012.03.012

BOWERING, W. R. 1983. Age, growth, and sexual maturity of Greenland halibut, Reinhardtius hippoglossoides (Walbaum), in the Canadian Northwest Atlantic. Fish. Bull., 81: 599-611.

BOWERING, W. R. and W. B. BRODIE. 1995. Greenland halibut (Reinhardtius hippoglossoides). A review of the dynamics of its distribution and fisheries off eastern Canada and Greenland. In: Deep-water fisheries of the North Atlantic oceanic slope. A. G. Hopper, (ed.). Kluwer Academic Publishers, p. 113-160.

BÄNÓN, R. 2001. New record of Cataetyx laticeps (Bythitidae) in Northwestern Atlantic. Cybium, 25: 93-94.

CARROTHERS, P. J. G. 1988. Scotia-Fundy groundfish survey trawls. Can. Tech. Rep. Fish. Aquat. Sci., 1609: iv+27 p.

CARUSO, J. H. 2002. Order Lophiiformes: Chaunacidae. In: The Living Marine Resources of the Western Central Atlantic. K. E. Carpenter, FAO. Rome, 2: 1052-1053.

CLARKE, K. R. and R. N. GORLEY. 2006. PRIMER v6: User Manual/Tutorial. PRIMER-E, Plymouth, UK. 190 p.

COHEN, D. M., T. INADA, T. IWAMOTO and N. SCIALABBA. 1990. Gadiform fishes of the world (Order Gadiformes). An annotated and illustrated catalogue of cods, hakes, grenadiers and other gadiform fishes known to date. FAO species catalogue Vol. 10, FAO Fisheries Synopsis, No. 125.

ESCHMEYER, W. N. and R. FRICKE. 2012. Catalog of Fishes electronic version (12 Jan 2012). http://research.calacademy. org/research/ichthyology/catalog/fishcatmain.asp.

GEISTDOERFER, P. 1986. Macrouridae. In: Fishes of the Northeastern Atlantic and the Mediterranean. P. J. P. Whitehead, M.-L. Bauchot, J.-C. Hureau, J. Nielsen and E. Tortonese (eds.). FAO, Paris, 2: 644-676.

GEISTDOERFER, P. 1990. Macrouridae. In: Check-list of the fishes of the tropical Atlantic, Clofeta. J. C. Quéro, J. C. Hureau, C. Karrer, A. Post, and L. Saldanha. UNESCO, Junta Nacional de Investigaçăo Cientifica e Tecnológica, Lisbon, 2: 541-563.

GOODE, G. B. and T. H. BEAN. 1896. Oceanic Ichthyology. Deep-sea and pelagic fishes of the world. Spec. Bull. U.S. Nat. Mus., 2: 553 p.

HAEDRICH, R. L. and N. R. MERRETT. 1988. Summary atlas of deep-living demersal fishes in the North Atlantic Basin. J. Nat. Hist., 22: 1325-1362. http://dx.doi. org/10.1080/00222938800770811

HAEDRICH, R. L., G. T. ROWE and P. T. POLLONI. 1975. Zonation and faunal composition of epibenthic populations on the continental slope south of New England. J. Mar. Res., 33: 191-212.

HAEDRICH, R. L., G. T. ROWE and P. T. POLLONI. 1980. The 
megabenthic fauna in the deep sea south of New England, USA. Mar. Biol., 57: 165-179. http://dx.doi.org/10.1007/ BF00390735

HARTEL, K. E., C. P. KENALEY, J. K. GALBRAITH and T. T. SUTTON. 2008. Additional records of deep-sea fishes from off Greater New England. Northeastern Naturalist, 15: 317-334. http://dx.doi.org/10.1656/1092-6194-15.3.317

ICES. 2008. Report of the Planning Group on the North-east Atlantic Continental Slope Survey (PGNEACS). ICES CM 2008/LRC:02, 38 p.

IWAMOTO, T. 2002. Macrouridae. In: The living marine resources of the Western Central Atlantic. K. E. Carpenter, FAO, Rome. Vol. 2: 977-987.

KULKA, D. W. MS 2006. Abundance and distribution of demersal sharks on the Grand Banks with particular reference to the NAFO Regulatory Area. NAFO SCR Doc., 06/20 Serial No. N5237, 36 p.

MARKLE, D. F., M. J. DADSWELL and R. G. HALLIDAY. 1988. Demersal fish and decapod crustacean fauna of the upper continental slope off Nova Scotia from LaHave to St. Pierre Banks. Can. J. Zool., 66: 1952-1960. http://dx.doi. org/10.1139/z88-286

MARKLE, D. F. and J. A. MUSICK. 1974. Benthic-slope fishes found at $900 \mathrm{~m}$ depth along a transect in the western N. Atlantic Ocean. Mar. Biol., 26: 225-233.

McEACHRAN, J. D. and J. D. FECHHELM. 1998. Fishes of the Gulf of Mexico. University of Texas Press, Austin, 1112 p.

MOORE, J., K. E. HARTEL, J. E. CRADDOCK and J. K. GALBRAITH. 2003. An annotated list of deepwater fishes from off the New England region, with new area records. Northeastern Naturalist, 10: 159-248.

MURUA, H., F. GONZÁLEZ and D. POWER. 2005. A review of the fishery and the investigations of roughhead grenadier (Macrourus berglax) in Flemish Cap and Flemish Pass. J. Northw. Atl. Fish. Sci., 37: 13-27. http://dx.doi. org/10.2960/J.v37.m567

MØLLER, P. R., J. G. NIELSEN, S. W. KNUDSEN, J. Y. POULSEN, K. SÜNKSEN and O. A. JØRGENSEN. 2010. A checklist of the fish fauna of Greenland waters. Zootaxa, No. 2378: 1-845.
PINHORN, A. T. and R. G. HALLIDAY. 1997. The Tail of the Grand Bank, southeast of Newfoundland, as a geographical boundary for continental slope fishes. Can. J. Zool., 75: 1753-1772. http://dx.doi.org/10.1139/z97-805

PINHORN, A. T. (ed.) 1976. Living marine resources of Newfoundland - Labrador: status and potential. Bull. Fish. Res. Bd. Can., 194: 64 p.

ROULE, L. and F. ANGEL. 1933. Poissons provenant des campagnes du Prince Albert I de Monaco. Résult. Camp. Scient. Prince Albert I, 86: 1-115, 4 pl.

SCOTT, W. B. and M. G. SCOTT. 1988. Atlantic Fishes of Canada. Can. Bull. Fish. Aquat. Sci., 219: 731 p.

SNELGROVE, P. V. R. and R. L. HAEDRICH. 1985. Structure of the deep demersal fish fauna off Newfoundland. Mar Ecol. Prog. Ser., 27: 99-107. http://dx.doi.org/10.3354/ meps027099

SULAK, K. J. 1982. A comparative taxonomic and ecological analysis of temperate and tropical demersal deep-sea fish faunas in the western North Atlantic. Ph.D. dissertation, Rosenstiel School of Marine and Atmospheric Science, University of Miami, Miami, Florida, USA, 211 .

SULAK, K. J. 1990. Halosauridae. In: Checklist of the fishes of the tropical Atlantic, Clofeta. J. C. Quéro, J. C. Hureau, C. Karrer, A. Post and L. Saldanha. UNESCO, Junta Nacional de Investigaçäo Cientifica e Tecnológica, Lisbon, 1: $126-132$.

SULAK, K. J., P. D. MACWHIRTER, K. E. LUKE, A. D. NOREM, J. M. MILLER, J. A. COOPER and L. E. HARRIS. 2009. Identification guide to skates (Family Rajidae) of the Canadian Atlantic and adjacent regions. Can. Tech. Rep. Fish. Aquat. Sci., 2850: viii+34 p.

TEMPLEMAN, W. 1966. A record of Bathypterois dubius Vaillant from the western North Atlantic, and review of status of the species. J. Fish. Res. Bd. Canada, 23: 715-722. http://dx.doi.org/10.1139/f66-061

THEMELIS, D. E. and R. G. HALLIDAY. 2012. Species composition and relative abundance of the mesopelagic fish fauna in the Slope Sea off Nova Scotia, Canada. Northeastern Naturalist, 19: 177-200. http://dx.doi. org/10.1656/045.019.0204 